\title{
A CLAIM TO FAME: THOMAS SYDENHAM
}

By J. S. Stewart

' Nothing so difficult as a beginning,' wrote Byron of poetry. To record that Thomas Sydenham was born on September 10, 1624, at Wynford Eagle in Dorsetshire, where his father, William Sydenham, of strong Puritan family, had a fine estate, is an admissible introduction to a detailed account of his life, but sounds quaint as a basis for his subsequent renown. That he was 'the English Hippocrates' is the standard opening for a biographical note on his achievements. Perhaps the description of the physician in the last book of the Aeneid can well be borrowed to introduce some thoughts on the claim to fame of the man who, modestly avoiding publicity, practised medicine first and foremost as an art. 'It was his part to learn the powers of medicines and the practice of healing and, careless of fame, to exercise that quiet art.' To this study Sydenham devoted himself by 'collecting as genuine and natural a description or history of all diseases as can be procured.'

A current definition of ill health is "the failure of the body and mind to adapt themselves to the environment-a failure which is the resultant of two factors, the imperfection of human nature and the hostility of the environment' (Roberts, I952). This definition is both precise and comprehensive and makes an immediate appeal; but in the case of acute organic disease Sydenham's more intimate approach seems to lead to a more personal inside knowledge. 'A disease, in my opinion, how prejudicial soever its causes may be to the body, is no more than a vigorous effort of nature to throw off the morbific matter, and thus recover the patient.' For ill health in its widest sense the modern definition may well be more comprehensive and more accurate, but does not the idea of ' a vigorous effort of nature ' produce a greater insight into the essence of acute organic disease than the idea of failure?

By his observations on the natural history of disease and his devotion to the cure of the patient, Sydenham established his greatest claim to fame. Before studying these and further reasons for his renown, it may be of interest to note some events of his life and the views of his contemporaries. In 1642 , at the ag 2 of 18 , he entered Magdalen Hall, Oxford, but soon left to serve, first as a trooper and later as a captain, in the army of Parliament. This he did with his usual vigour, being 'left on the field among the dead' after one battle and, on another occasion, being saved from the bullet of a pistol fired at arm's length by the chance position of the left hand of his drunken assailant, who was gripping him by the shirt. In 1647 he returned to Oxford, this time to study medicine, and after spending only six months there was created Bachelor of Medicine by order of the Earl of Pembroke, Chancellor of the University. Even in those days this was regarded as a highly irregular procedure, the more especially as he had not taken a degree in arts. About nine or ten years later he studied under the celebrated Barbeyrac at Montpellier, and on returning to England practised in London for a year or two before obtaining, by examination, the licence of the Royal College of Physicians to practise in the City of London and seven miles round. This was his only link with the Royal College, partly for political reasons and partly because some of the Fellows considered him as an upstart and an imposter. He was a personal friend, however, of some of his greatest contemporaries, including the Hon. Robert Boyle (1627-9I), to whom he wrote, in the last year of his life (I689), 'I have the happiness of curing my patients, at least of having it said concerning me that few miscarry under me; but I cannot brag of my correspondency with some other of my faculty.'

The situation is well seen in Dr. Andrew Brown's book, published in Edinburgh in 1691 and entitled 'A Vindicatory Schedule concerning the new Cure of Fevers, containing a disquisition, theoretical and practical, of the new and most effectual method of curing continual fevers, first invented and delivered, by the sagacious Dr. Thomas Sydenham.' Dr. Brown describes his first reactions: 'In the year 1687 , perusing the 
first edition of his Schedula Monitoria, where he delivers, as confirmed by manifold experiences, not only a new, but a quite contrarie method to the common, of curing Continual Fevers, I did not long hesitate (setting forth to visit him), thinking that either he, or all other physicians, were grossly deceived about the cure of Fevers.' After spending some months with Sydenham the Edinburgh doctor returned home ' as much overjoyed as I had gotten a treasure, I presently set myself to the practice.' Besides Dr. Andrew Brown other contemporaries who bore still extant testimony to Sydenham's skill were Dr. Thomas Dover (1660-1 742), of Dover's powder fame, and John Locke (1632-1704). The last was a close friend and, at one time, a colleague of the man he described as 'one of the master builders at this time in the commonwealth of learning.' Both Locke and Sydenham were sufficiently unorthodox to doubt the suitability of polypharmacy and even of placebos.

'I do not think it below me or my art to acknowledge, with respect to the cure of fevers and other distempers, that when no manifest indication pointed out to me what should be done, I have consulted my patient's safety, and my own reputation, most effectually, by doing nothing at all' (Sydenham). Dr. Dover, patient as well as pupil, has described how Sydenham treated his smallpox. The regimen was based on the cooling principle, with no fire, open windows and few bedclothes, and included 'twelve bottles of Small Beer every twenty-four hours' (see Bailey, 1944). The beer, however, was ' acidulated with spirit of vitriol.' Munk even says that the name of Sydenham was always mentioned with respect in the Royal College. Opinion among physicians, at first divided, grew gradually in Sydenham's favour throughout, and especially after, his lifetime.

That there should have been much opposition is in no way surprising seeing that current medicine was so largely academic. It was based not so much on practice as on the theories of the different schools of thought, chief among which were the iatro-physicists, who sought to explain disease on a physical basis, and the iatro-chemists, who saw in every disease only a disturbance of the acidalkali balance. For doctrines founded on speculation and preached with dogma the father of English practical medicine substituted ' downright matter of fact' gained by 'faithful observation' and accurate note-taking at the bedside.

'He knew what's what, and that's as high

As metaphysic wit can fly.'

(Samuel Butler: Hudibras, Pt. I, I663.)

While Sydenham was doing this for medical thought, Locke was doing much the same for philosophy. As Dr. John Brown says in 'Horae
Subsecivae,' ' They pointed out a way, and themselves walked in it; they taught a method and used it, rather than announced a system or discovery; $\stackrel{\mathbb{Q}}{\complement}$ they collected and arranged their "visa" before $C$. settling their " cogitata" $\longrightarrow$ a mean-spirited pro- $\overrightarrow{\vec{B}}$ cedure doubtless in the eyes of the prevailing dealers in hypotheses, being in reality the exact reverse of their philosophy.'

During and shortly after his lifetime, Sydenham's reputation on the Continent was greater than it was in his own country, where it rested के largely on his laudanum (the first form of a $\overrightarrow{0}$ tincture of opium), his cooling treatment for smallpox, and his use of Peruvian bark in quartan agues. $\vec{\omega}$ It was only 20 years after his death that Leyden University appointed to its Chair of Botany and Medicine the renowned Hermann Boerhaave (16681738). If English medical students know anything about 'the English Hippocrates' it is that Boerhaave 'was wont to take his hat off whenever he ol mentioned his name,' that Sydenham did 'some of things for his profession which, considering the dark age in which he worked, were highly to his credit,' and that his name is connected with the rheumatic type of chorea, to be distinguished from the hereditary type of Huntington (1851-1916). Further investigation reveals that he "recorded 3 his own sufferings from the gout in a clever and 음 entertaining way,' and that he was responsible fo् several classic descriptions of diseases, notab of smallpox, measles and scarlet fever.

Sydenham's present claim to fame rests chiefly on his ' natural history' method in the study of disease, his stress on the importance of direct observation and his advocacy of the return from current theoretical speculations to the practical $\stackrel{\square}{\unrhd}$ bedside medicine of Hippocrates. In present-day $\overrightarrow{\vec{O}}$ American opinion 'Sydenham stands out as the 3 greatest representative of the practical medicine $\bar{F}$ of practical England' (Major, 1948). As R. G. Latham points out in his biography, there can be no doubt that other reasons for the admiration of 3 . posterity are " the moral elements of a liberal and candid spirit (which) went hand in hand with the intellectual qualifications of observation, analysis 0 and comparison.'

Of the problems that occupied the great 을 clinician's mind many still remain to perplex us today. Not the least of these are associated with epidemiology. Sydenham made a close study of the various fevers and other acute maladies of ${ }^{\mathrm{T}}$ London over a series of years, including $1665, N$ when the Great Plague was at its worst. (It is interesting to note that he obtained his M.D. ato Cambridge two years after this.) He found thato the type of acute disease varied according to the year and the season, and the right treatment could? not be adopted until the type was known. Sincer 
the Hippocratic treatise 'On airs, waters and places' there had been nothing quite like this in medical literature. "I have carefully examined the different constitutions of different years, as to the manifest qualities of the air, yet I must own I have hitherto made no progress, having found that years, perfectly agreeing as to their temperature and other sensible properties, have produced very different tribes of diseases and vice versa.' A remarkably similar type of difficulty, considering the extraordinary advances in knowledge, confronts the writer of 'Figures and 'Flu' in the British Medical fournal, September 20, 1952: 'The spread all over Great Britain between the week ending January 2 (195I) and that ending January 9 was phenomenally rapid; it is hard to believe that any transference due to ordinary man-to-man contact could have proceeded with that speed. Naturally thoughts arise of preseeding of virus and all but simultaneous activation of that widely scattered seed. On the other hand, the start of the epidemic round East Coast ports most apt to be infected from Scandinavia induces quite a different train of thought. There is something odd here waiting to be found out.' It is presumably a good thing that the solution so often appears to be waiting just round the corner.

The study of Sydenham and his work seems almost inevitably, at some point, to call to mind the dual nature of medicine. As a science medicine demands the precise recording of accurate observations, their apposite correlation and the drawing of logical conclusions. As an art it must be practised with tact, understanding and sound judgment. These two methods of approach do not so much represent two separate types of doctor or of practice as one complementary duality. Nevertheless, we tend to associate some names with one conception, others with the other. The word 'science' is best taken in its broadest sense, as used by Einstein in his recent book, 'Out of my Later Years,' where he describes it as 'the striving after the rational unification of the manifold.' On the one hand are the 'theories of principles,' such as Thermodynamics and the Theory of Relativity, where the method is analytic and the process one of deduction from a general principle to every case that presents itself. On the other hand are the synthetic theories, in which many observed occurrences are built into one whole framework or intellectual scaffolding. There are two approaches here also; the idea of duality is common to several spheres of thought. In both methods the aim is the same-to produce a rationally unified concept of a multitude of events. In the sense that he reasoned by induction from the particular to the general, Harvey stands out primarily as a man of science. As a result his work remains a monument to his name throughout the centuries, and its applications have benefited countless numbers. But would the individual patient lying ' sick of a fever' choose Harvey or Sydenham to attend him?

In regarding Sydenham primarily as one who practised the art of medicine it is not intended to suggest that he made no use of the scientific method. But in his application of 'middle propositions' rather than complete hypotheses, in his practical use of theory in order to act, and in his exercise of judgment based on experience, his work appears as the product of the physician's art rather than as medical science. As a result of his devotion to immediate needs much that was best in him died with him. But the record of his work still serves to keep his memory alive and to link his name with that of Hippocrates himself. $\mathrm{He}$ set a high standard and took pains to maintain it. ' In writing, therefore, a history of diseases, every philosophical hypothesis which hath prepossessed the writer in its favour ought to be totally laid aside, and then the manifest and natural phenomena of diseases, however minute, must be noted with the utmost accuracy, imitating in this the great exactness of painters, who in their picture copy the smallest spots or moles in the originals; for it is difficult to give a detail of the numerous errors that spring from hypothesis ...' It was just this 'axpíßzia or nicety of observation' that went to make Thomas Sydenham the closest English disciple of Hippocrates and 'the greatest representative of the practical medicine of practical England.'

\section{BIBLIOGRAPHY}

BAILEY, H., and BISHOP, W. J. (1944), 'Notable Names in Medicine and Surgery,' H. K. Lewis, London.

BROWN, J. (1898), 'Horae Subsecivae,' Adam \& Charles Black, London.

EINSTEIN, A. (1950), ' Out of my Later Years,' Thomas \& Hudson, London.

LATHAM, R. G. (1848-50), 'The Works of Thomas Sydenham,

M.D., Translated from the Latin Edition of Dr. Greenhill, with 'a Life of the Author.' Printed for the Sydenham Society, London.

MAJOR, R. H. (1948), 'Classic Descriptions of Disease, Springfield, Illinois.

ROBERTS, FRANGCON (1952), "The Cost of Health,' Turnstile Press, London. 